\title{
Effects of Different Levels of Oxalic Acid Administration on Feed Intake and Nutrient Digestibility in Goats
}

(Kesan daripada Pelbagai Tahap Pemberian Asid Oksalik ke atas Pengambilan Makanan dan Kebolehhadaman Nutrien pada Kambing)

\author{
MOHAMmad Mijanur RaHMAN*, MD. RoKibur RAHMAn, MitsuHiRo NiImi, \\ WAN EMBONG WAN KHADIJAH, RYO AKASHI \& RAMLI BIN ABDULLAH
}

\begin{abstract}
An experiment was carried out to investigate the effects of oxalic acid administration on feed intake and nutrient digestibility in goats. Four female cross bred (Boer $\times$ local) goats (average body weight of $46.3 \mathrm{~kg}$ ) were randomly assigned to four experimental diets including oxalic acid administration at levels of $0,2.25,4.50$ and $6.75 \mathrm{~g} / \mathrm{animal} / \mathrm{d}$ in a $4 \times 4$ Latin Square design. Oxalic acid diluted with water was administered orally via syringe to experimental goats once daily for four experimental periods. Each experimental period was lasted $21 \mathrm{~d}$ in length, comprising $14 \mathrm{~d}$ of adaptation to the experimental diet followed by $7 d$ of data collection. All the animals were individually fed with Napier grass ad libitum supplemented with $300 \mathrm{~g}$ (fresh basis) pelleted compound feed per goat per day throughout the study. Feed composition, feed intake, nutrient intake and nutrient digestibility were determined. Intakes of dry matter (DM), organic matter (OM), crude protein (CP), neutral detergent fibre (NDF) and metabolisable energy tended to linearly decrease with the increasing rate of oxalic acid administration, with the value in the $6.75 \mathrm{~g}$ oxalic acid/animal/d treatment being significantly $(\mathrm{p}<0.05)$ lower than the control $(0 \mathrm{~g}$ oxalic acid/animal/d) treatment. The oxalic acid administration had no effect on apparent digestibilities of DM, OM, $C P$ and NDF. The experiment demonstrated that oxalic acid administration may influence in the DM and nutrient intakes, but not influence on DM and nutrient digestibilities in goats.
\end{abstract}

Keywords: Feed intake; goats; nutrient digestibility; oxalic acid

ABSTRAK

Penyelidikan ini telah dijalankan untuk mengkaji kesan pemberian asid oksalik ke atas pengambilan makanan dan kebolehhadaman nutrien dalam kambing. Empat baka kacukan kambing betina (Boer $\times$ tempatan) (berat badan purata $46.3 \mathrm{~kg}$ ) secara rawak telah diperuntukkan kepada empat uji kaji diet termasuk pemberian asid oksalik pada peringkat 0 , 2.25, 4.50 dan $6.75 \mathrm{~g} /$ haiwan/hari dalam reka bentuk segi empat sama Latin $4 \times 4$. Asid oksalik yang dicairkan dengan air diberi secara oral melalui picagari untuk kambing uji kaji sekali sehari untuk tempoh empat uji kaji. Setiap tempoh uji kaji telah berlangsung selama 21 hari; 14 hari untuk penyesuaian diet uji kaji diikuti dengan 7 hari pengumpulan data. Semua haiwan secara individu telah diberi makan rumput Napier secara ad libitum ditambah dengan sebatian pelet $300 \mathrm{~g}$ (segar) setiap hari sepanjang kajian ini. Pengambilan komposisi, pengambilan makanan, pengambilan nutrien serta kebolehhadaman nutrien telah ditentukan. Pengambilan bahan kering (DM), bahan organik (OM), protein kasar (CP), gentian detergen neutral (NDF) dan tenaga boleh dimetabolis cenderung untuk mengurangkan secara linear kadar peningkatan asid oksalik, dengan nilai rawatan asid/haiwan/hari 6.75 g secara bererti $(\mathrm{p}<0.05)$ lebih rendah berbanding kawalan (0 g asid/haiwan/hari). Pemberian asid oksalik tidak mempunyai kesan yang jelas ke atas kebolehhadaman DM, OM, CP dan NDF. Kajian ini menunjukkan bahawa pemberian asid oksalik boleh mempengaruhi pengambilan DM dan nutrien, tetapi tidak mempengaruhi DM dan kebolehhadaman nutrien dalam kambing.

Kata kunci: Asid; kambing; kebolehhadaman nutrien; pengambilan makanan

\section{INTRODUCTION}

Many forage plants fed by animals are high in oxalates mainly halophytes such as Atriplex sp. and Kochia sp. (Rahman \& Kawamura 2011). Oxalates are needed by plants for osmoregulation of some minerals ions (Cymbaluk et al. 1986) but can be toxic to livestock (Rahman et al. 2013). These oxalates could have direct and indirect effects on animal performance and health. The direct effect is induced by the soluble oxalates which are absorbed and accumulate in the kidney resulting in animal intoxication (James 1972). The indirect effect is caused by insoluble oxalates which have an affinity to calcium $(\mathrm{Ca})$ and magnesium $(\mathrm{Mg})$ rendering these minerals unavailable for the microflora and the host animal (Vonburg 1994). When the animal is consuming low Ca-diets, then the insoluble oxalates would fix the $\mathrm{Ca}$-skeleton causing some pathological diseases. It is generally accepted that ruminants can degrade certain levels of oxalate salts into 
harmless formic acid and carbon dioxide (Allison et al. 1977).

Most studies have been conducted on oxalate degradation in the rumen and blood $\mathrm{Ca}$ level in response to different levels of dietary oxalate (Allison et al. 1985; Duncan et al. 1997; Hsieh et al. 2004; Rahman et al. 2013). A study with sheep and goats showed that the administration of free oxalic acid led to changes in the rate of oxalic acid breakdown in the rumen, particularly of goats, thus protecting the host animal from toxic symptoms (Duncan et al 1997). Duncan et al. (1997) also reported that goat's rumen is a special place for the microbial population which degrades oxalic acid more rapidly. Frutos et al. (1998) observed that goats were adapted to oxalic acid by daily oral administration of $3.4 \mathrm{~g}$ oxalic acid/animal/d of free oxalic acid, which successfully generated an active oxalic acid-degrading rumen microbial population, though goats showed a chronic mild hypocalcaemia.

The palatability of a feed has been related to both physical characteristics (texture) and the presence of compounds (oxalic acid) which may affect taste and appetite. Oxalic acid is typically a corrosive substance and acidic, which can produce a sour taste in the mouth. Further, needle-like oxalate crystals cause pain and swelling when they contact lips, tongue and oral mucosa (Franceschi \& Horner 1980). Rahman et al.(2013) reported that some oxalate-rich plants contain abundant $\mathrm{Ca}$ (e.g. Medicago sativa), which are safe to feed despite their high oxalate content. However, some plants have extremely high amounts of oxalate such as halogeton, wood sorrels and rhubarb leaves (Rahman \& Kawamura 2011). In addition, Napier grass is an important forage for ruminants, but its soluble oxalate concentration has also been reported relatively high ( $>4.0 \%$ of dry matter) (Rahman et al. 2006).

Oxalate has a very low energy value (Roughan \& Slack 1973) and it would appear in the digestible fraction of dry matter (DM) digestibility. Hacker (1974) reported that oxalate content contributed relatively little to the DM digestibility of setaria grass. Oxalate can decrease the $\mathrm{Ca}$ digestibility in forages if the Ca-to-oxalate ratio in the forage is 0.5 or less on a weight-to-weight basis (Hintz 1990). On the other hand, no difference was observed in the Ca digestibility from alfalfa containing $0.5 \%$ and $0.9 \%$ oxalic acid in which the Ca:oxalate ratios were 3 and 1.7, respectively (Hintz et al. 1984). Information on voluntary intake and digestibility of oxalate-containing grasses fed by goats is limited. It was hypothesised that adding concentrate may alleviate the negative effect of oxalate because of higher Ca added (Perry 1984). Therefore, the objectives of this study were to investigate the effects of different levels of oxalic acid administration on the intake and nutrient digestibility of goats fed Napier grass and concentrate supplementation.

\section{MATERIALS AND METHODS}

This study was carried out at the Institute of Biological Sciences mini-farm of the University of Malaya, Kuala
Lumpur, Malaysia from mid-June to mid-September 2013. All procedures and animal handling during the feeding experiments were conducted according to the guidelines of the Institutional Animal Care and Use Committee of the University of Malaya. Four female crossbred (Boer×local) goats (BW 46.3 $\pm 2.42 \mathrm{~kg}$ and 4-5 years of age) were randomly allocated to four levels of oxalic acid administration $(0,2.25,4.50$ and $6.75 \mathrm{~g}$ oxalic acid/animal/d) according to a $4 \times 4$ Latin square design to determine the effects of different levels of oxalic acid administration on feed intake and nutrient digestibility. For individual goat, oxalic acid diluted with water was administered to treatment by once daily oral dosing at 09:00 $\mathrm{h}$ for four experimental periods. This was achieved by giving $50 \mathrm{~mL}$ daily, orally via syringe. Each experimental period was $21 \mathrm{~d}$ in length, comprising $14 \mathrm{~d}$ of adaptation to the experimental diet followed by $7 \mathrm{~d}$ of data collection. Goats were individually fed Napier grass ad libitum supplemented with $300 \mathrm{~g}$ (fresh basis) pelleted compound feed per goat per day throughout the study. Goats were placed in the individual pen and fresh water was offered free choice. The chemical composition of the pelleted compound feed and Napier grass fed to the goats in this study is shown in Table 1.

Daily recording of feed offered to each goat in all the treatment groups and residue left by each goat were recorded. During the last seven days of each period, feed offered, refusals and total faeces were recorded and sampled daily. Faeces were collected from each goat at $0900 \mathrm{~h}$ on each day of the 7-day faecal collection. These faecal collections were pooled to provide one faecal sample from each animal. Faeces samples were pooled by period prior to analysis. All samples were dried at $70^{\circ} \mathrm{C}$ for $48 \mathrm{~h}$ and ground in a Willey mill to pass through $1 \mathrm{~mm}$ sieve and stored in airtight plastic containers for chemical analysis. Feeds and faeces samples were analysed for DM, nitrogen (N) and ash according to AOAC (1995). Organic matter (OM) was determined by subtracting ashes from 100 . Neutral detergent fibre (NDF) was determined as described by van Soest et al. (1991) without alpha-amylase and expressed inclusive of residual ash. The feed samples were analysed for soluble oxalate content by the method of Rahman et al. (2007). The potassium (K), sodium (Na), Ca and Mg concentrations in the samples were determined using the flame atomic spectroscopy method after wet digestion with nitric acid and hydrogen peroxide (The University of Tokyo 1978).

All data were analysed as a $4 \times 4$ Latin Square design using the compare means of SPSS (version 12, SPSS Inc., Chigago, IL, USA), based on the statistical model:

$$
\mathrm{Y}_{i j k l}=\mu+\mathrm{G}_{i}+\mathrm{P}_{j}+\mathrm{T}_{k}+\mathrm{e}_{i j k l} \text {, }
$$

where $\mu$ is the overall mean; $\mathrm{G}_{i}$ is the effect of goat $(i=1$ to 4 ); $\mathrm{P}_{j}$ is the effect of period ( $j=1$ to 4$), \mathrm{T}_{k}$ is the fixed effect of treatment $(k=1$ to 4$)$ and $\mathrm{e}_{i j k l}$ is the residual error. When the treatment effect was significant $(p<0.05)$, differences among means were tested with Duncan's 
TABLE 1. Chemical composition ( $\mathrm{g} / \mathrm{kg} \mathrm{DM})$ of Napier grass and pelleted compound feed

\begin{tabular}{ccc}
\hline Item & Napier grass & Pelleted compound feed $^{\delta}$ \\
\hline $\mathrm{DM}(\mathrm{g} \mathrm{DM} / \mathrm{kg}$ fresh weight $)$ & 240 & 901 \\
$\mathrm{OM}$ & 914 & 932 \\
$\mathrm{CP}$ & 104 & 151 \\
$\mathrm{NDF}$ & 555 & 239 \\
$\mathrm{Ca}$ & 2.6 & 11.5 \\
$\mathrm{Mg}$ & 2.6 & 8.5 \\
$\mathrm{Na}$ & 0.3 & 1.0 \\
$\mathrm{~K}$ & 53.9 & 14.1 \\
$\mathrm{Ash}$ & 86 & 68 \\
Soluble oxalate & 23 & 0 \\
ME (MJ/kg) & & 11.7 \\
\hline
\end{tabular}

DM, dry matter; OM, organic matter; CP, crude protein; NDF, neutral detergent fibre; Ca, calcium; Mg, magnesium; Na, sodium; K, potassium; ME, metabolisable energy. ${ }^{\delta}$ The pelleted compound feed was manufactured by FFM Marketing Sdn. Bhd. (Selangor, Malaysia) and it contained maize, wheat, wheat bran, rice bran, soybean meal, sesame meal, molasses, limestone, dicalcium phosphate, salt and feed additives. ${ }^{\beta}$ The $\mathrm{ME}$ values of the feeds were calculated with the following equation (AFRC 1993): ME $(\mathrm{MJ} / \mathrm{kg} \mathrm{DM})=0.016 \times$ digestible organic matter

multiple range test. Orthogonal polynomial contrasts were used to examine the responses (linear and quadratic) to an increase in the levels of oxalic acid administration.

\section{RESULTS AND DISCUSSION}

The mean of grass DM, total DM, nutrient and ME intakes are presented in Table 2. The pelleted compound feed was accepted by the goats with no refusals in all treatments. A linear effect of the different levels of oxalic acid administration was detected for DM intake, nutrient intake and ME intake $(p<0.01)$ and the intake values tended to decrease with the increasing rate of oxalic acid administration, with the value in the $6.75 \mathrm{~g}$ oxalic acid/ animal/d treatment being significantly $(p<0.05)$ lower than the control $(0 \mathrm{~g}$ oxalic acid/animal/d) treatment. It is generally accepted that animals eat less feed, if the feed contains a toxin (Burritt \& Provenza 2000), perhaps because of low palatability. In the present study, animals received oxalic acid not only by the oral administration but also received from oxalate-containing Napier grass. The used Napier grass in the present study contained $23 \mathrm{~g}$ soluble oxalate/kg DM (Table 1) and this result was supported by previous findings of Rahman et al. (2006) who reported that Napier grass can accumulate soluble oxalate as relatively high (up to $48 \mathrm{~g} / \mathrm{kg} \mathrm{DM}$ ). Based on calculation (soluble oxalate content of Napier grass and orally administered oxalic acid), oxalate concentration for $0,2.25,4.50$ and $6.75 \mathrm{~g}$ oxalic acid/animal/d treatments were $1.7,1.9,2.1$ and $2.4 \%$ of the total diet, respectively. Most of the forages consumed by animals usually accumulate soluble oxalate approximately 1.0 to $2.0 \%$ of DM (Libert \& Franceschi 1987), which are similar to the levels in the present study.

The $6.75 \mathrm{~g}$ oxalic acid/animal/d treatment in this study exhibited significantly lower values including DM, nutrients and ME intakes than the control treatment. This finding is confirmed by Kyriazakis et al. (1998) and Burritt and Provenza (2000) who reported that oxalate-rich plants were responsible for reduced feed intake. Burritt and Provenza (2000) observed that voluntary feed intake is significantly depressed by feeding of ration containing $30 \mathrm{~g}$ oxalate $/ \mathrm{kg}$ DM. James et al. (1968) reported that ingestion of oxalaterich plants tends to increase an animal's water intake and urine excretion. In the current study, oxalate-rich diet might be the reason for the reduction of intake in goats receiving treatment of $6.75 \mathrm{~g}$ oxalic acid/animal/d, which may affect the palatability of diet. It is noted that soluble oxalates are found in a form of $\mathrm{K}, \mathrm{Na}$ and ammonium salts (Rahman \& Kawamura 2011) and high concentrations of these salts $\left(\mathrm{Na}^{+}\right.$and $\left.\mathrm{K}^{+}\right)$in the extracellular fluid of the rumen mucosa may be involved in reducing voluntary feed intake (Masters et al. 2005).

The present study also showed no difference $(p>0.05)$ in feed intake among $0,2.25$ and $4.50 \mathrm{~g}$ oxalic acid/ animal/d treatments might be due to the lower levels of oxalic acid in the total diets, which is agreed with the findings of Rahman et al. (2011) who found that no differences $(p>0.05)$ were observed in feed intake between the feeding of low ( $4.7 \mathrm{~g}$ soluble oxalate $/ \mathrm{kg} \mathrm{DM})$ and high (13.4 g soluble oxalate/kg DM) oxalate-containing grasses. In the current study, no difference in intake due to low levels (0 to $4.50 \mathrm{~g}$ oxalic acid/animal/d) of oxalic acid was observed and this could be due to factors such as the amount of oxalate administered, rumen microorganism and adaptation to diets. For example, Allison et al. (1977) reported that certain levels of oxalate can be degraded by rumen microorganisms. In addition, ruminants adapted to diets with high oxalate content can tolerate oxalate levels that are lethal to non-adapted animals (Rahman et al. 2013).

The current results indicated that feed intake may not be affected by low dietary levels ( 0 to $4.50 \mathrm{~g}$ oxalic acid/ animal/d) of oxalic acid, but it may affect by high dietary levels (6.75 g oxalic acid/animal/d). This conclusion is supported by Rahman et al. (2013) who suggested that limiting oxalate ingestion to $<2.0 \%$ soluble oxalate of feed (DM basis) would be appropriate for protecting the ruminants from oxalate poisoning. In the present 
TABLE 2. Effects of different levels of oxalic acid administration on DM and nutrient intakes in adult goats

\begin{tabular}{|c|c|c|c|c|c|c|c|}
\hline \multirow{2}{*}{ Item } & \multicolumn{4}{|c|}{ Dose rate of oxalic acid (g/animal/d) } & \multirow{2}{*}{ SEM } & \multicolumn{2}{|c|}{ Orthogonal contrast } \\
\hline & 0 & 2.25 & 4.50 & 6.75 & & Linear & Quadratic \\
\hline Grass DM intake (g/d) & $839^{\mathrm{a}}$ & $722^{\mathrm{ab}}$ & $703^{\mathrm{ab}}$ & $628^{b}$ & 28.52 & $<0.01$ & 0.62 \\
\hline Total DM intake $(\mathrm{g} / \mathrm{d})$ & $1109^{\mathrm{a}}$ & $992^{\mathrm{ab}}$ & $973^{\mathrm{ab}}$ & $898^{\mathrm{b}}$ & 28.52 & $<0.01$ & 0.62 \\
\hline Total OM intake $(\mathrm{g} / \mathrm{d})$ & $1017^{\mathrm{a}}$ & $910^{\mathrm{ab}}$ & $894^{\mathrm{ab}}$ & $824^{\mathrm{b}}$ & 26.02 & $<0.01$ & 0.61 \\
\hline Total CP intake $(\mathrm{g} / \mathrm{d})$ & $128.6^{\mathrm{a}}$ & $116.3^{\mathrm{ab}}$ & $114.4^{\mathrm{ab}}$ & $106.4^{\mathrm{b}}$ & 2.99 & $<0.01$ & 0.61 \\
\hline Total NDF intake (g/d) & $527^{\mathrm{a}}$ & $462^{\mathrm{ab}}$ & $452^{\mathrm{ab}}$ & $410^{\mathrm{b}}$ & 15.69 & $<0.01$ & 0.61 \\
\hline Total ME intake (Mcal/d) & $2.3^{\mathrm{a}}$ & $2.1^{\mathrm{ab}}$ & $2.0^{\mathrm{ab}}$ & $1.9^{\mathrm{b}}$ & 0.05 & $<0.01$ & 0.62 \\
\hline
\end{tabular}

DM, dry matter; OM, organic matter; CP, crude protein; NDF, neutral detergent fibre; ME, metabolisable energy; SEM, standard error of means; Means within the same row with different letters are significantly different $(p<0.05)$

TABLE 3. Effects of different levels of oxalic acid administration on dry matters and nutrient digestibility in adult goats

\begin{tabular}{|c|c|c|c|c|c|c|c|}
\hline \multirow{2}{*}{ Item } & \multicolumn{4}{|c|}{ Dose rate of oxalic acid (g/animal/d) } & \multirow{2}{*}{ SEM } & \multicolumn{2}{|c|}{ Orthogonal contrast } \\
\hline & 0 & 2.25 & 4.50 & 6.75 & & Linear & Quadratic \\
\hline \multicolumn{8}{|c|}{ Digestibility } \\
\hline $\mathrm{DM}$ & 60.2 & 63.2 & 59.2 & 57.9 & 1.79 & 0.54 & 0.46 \\
\hline $\mathrm{OM}$ & 62.1 & 65.1 & 60.4 & 60.4 & 1.69 & 0.58 & 0.53 \\
\hline $\mathrm{CP}$ & 71.6 & 76.5 & 73.4 & 73.7 & 1.32 & 0.65 & 0.27 \\
\hline NDF & 46.8 & 47.9 & 42.9 & 42.6 & 2.52 & 0.45 & 0.79 \\
\hline
\end{tabular}

DM, dry matter; OM, organic matter; CP, crude protein; NDF, neutral detergent fibre; SEM, standard error of means

study, insoluble oxalate content in the feeds was not determined, because insoluble oxalate is not considered to have a harmful effect on the body's metabolism as it seems to pass through the digestive tract (Ward et al. 1979), whereas soluble oxalate is likely to be absorbed in the intestine and cause chronic Ca deficiency (Blaney et al. 1982). Certain plants have extremely high amounts of oxalate such as halogeton, wood sorrels and rhubarb leaves (Rahman \& Kawamura 2011). For this reason, oral doses of oxalic acid were used in this study even though basal diet (Napier grass) contained moderate level (23 $\mathrm{g} / \mathrm{kg} \mathrm{DM}$ ) of soluble oxalate (Table 1). It is hard to find any agreement regarding a threshold level before signs of toxicity is exhibited in ruminants because of various factors involvement such as oxalate form, the amount of oxalate consumed and adaptation to a diet (Rahman et al. 2013). In their conclusion, authors suggested that soluble oxalate levels greater than $2.0 \%$ in ruminants and greater than $0.5 \%$ in non-ruminants can be considered the upper limits.

The mean of apparent digestibility including DM, OM, CP and NDF are presented in Table 3. In the present study, apparent digestibility of DM, OM, CP and NDF did not differ $(p>0.05)$ among the treatments. Our results are inconsistent with reports of James et al. (1968) who reported that DM and nitrogen digestibility were higher for the oxalatecontaining helogeton diet than control. This result might be explained by the adequate supply of compound pelleted feed in the present experiment, which did not affect the absorption of soluble ash from the digestive tract. James et al. (1967) suggested that oxalate feeding might be involved to reduce the cellulose fermentation, but the addition of various mineral supplements to the oxalatecontaining media enhanced the fermentation of cellulose. The difference in nutrient digestibility may be occurred by absorption of ash and degradation of oxalate in the rumen (James et al. 1968). These results suggested that responses to oxalic acid in terms of intake and digestibility in goats could depend on upon a diet composition, oxalate source (dietary administration/oxalate in plants) and their level of inclusion in the diet.

\section{CONCLUSION}

The results of this study demonstrate that feed intake can be affected by increasing levels of oxalic acid administration fed Napier grass and concentrate supplementation, but digestibility might not be affected. The study shows how differences in the rate of oxalic acid in the diet may influence feed intake and digestibility in ruminants.

\section{ACKNOWLEDGEMENTS}

This work was financially supported by IPPP Research Grant (BK006-2015) of University of Malaya.

\section{REFERENCES}

AFRC. 1993. Energy and Protein Requirements of Ruminants. CAB International, Wallingford, UK: Agricultural and Food Research Council. 
Allison, M.J., Dawson, K.A., Mayberry, W.R. \& Foss, J.G. 1985. Oxalobacter-formigenes Gen-Nov, Sp-Nov-Oxalatedegrading anaerobes that inhabit the gastrointestinal-tract. Archives of Microbiology 141(1): 1-7.

Allison, M.J., Littledike, E.T. \& James, L.F. 1977. Changes in ruminal oxalate degradation rates associated with adaptation of oxalate ingestion. Journal of Animal Science 45(5): 11731179 .

AOAC. 1995. Official Methods of Analysis, 16th ed. Arlington, VA, USA: Association of Official Analytical Chemists

Blaney, B.J., Gartner, R.J.W. \& Head, T.A. 1982. The effects of oxalate in tropical grasses on calcium, phosphorus and magnesium availability to cattle. Journal of Agricultural Science (Cambridge) 99(3): 533-539.

Burritt, E.A. \& Provenza, F.D. 2000. Role of toxins in intake of varied diets by sheep. Journal of Chemical Ecology 26(8): 1991-2005.

Cymbaluk, N.F., Miller, J.D. \& Christensen, D.A. 1986. Oxalate concentration in feeds and its metabolism by ponies. Canadian Journal of Animal Science 66(4): 1107-1116.

Duncan, A.J., Frutos, P. \& Young, S.A. 1997. Rates of oxalic acid degradation in the rumen of sheep and goats in response to different levels of oxalic acid administration. Animal Science 65(3): 451-456.

Franceschi, V.R. \& Horner, H.T. Jr. 1980. Calcium oxalate crystals in plants. Botanical Review 46(4): 361-427.

Frutos, P., Duncan, A.J., Kyriazakis, I. \& Gordon, I.J. 1998. Learned aversion towards oxalic acid-containing foods by goats: Does rumen adaptation to oxalic acid influence diet choice? Journal of Chemical Ecology 24(2): 383-397.

Hacker, J.B. 1974. Variation in oxalate, major cations, and dry matter digestibility of 47 introductions of the tropical grass setaria. Tropical Grasslands 8(3): 145-154.

Hintz, H.F., Schryver, H.F., Doty, J., Lakin, C. \& Zimmerman, R.A. 1984. Oxalic acid content of alfalfa hays and its influence on the availability of calcium, phosphorus and magnesium to ponies. Journal of Animal Science 58(4): 939-942.

Hintz, H.F. 1990. Factors affecting nutrient availability in the horse. In Proceedings 1990 Georgia Nutrition Conference. pp. 182-193.

Hsieh, W.C., Wang, D.C., Yan, S.S. \& Cheng, Y.K. 2004. Comparison of different oxalate contents of napiergrass fed to yellow cattle and goats. Journal of Taiwan Livestock Research 37(4): 313-322.

James, L.F. 1972. Oxalate toxicosis. Clinical Toxicology 5(2): 231-243.

James, L.F., Joseph, C.S. \& John, E.B. 1967. In vitro degradation of oxalate and of cellulose by rumen ingesta from sheep fed Halogeton glomeratus. Journal of Animal Science 26(6): 1438-1444.

James, L.F., Street, J.C., Butcher, J.E. \& Shupe, J.L. 1968. Oxalate metabolism in sheep. II. Effect of low level Halogeton glomeratus intake on electrolyte metabolism. Journal of Animal Science 27(3): 724-729.

Kyriazakis, I., Anderson, D.H. \& Duncan, A.J. 1998. Conditioned flavour aversions in sheep: The relationship between the dose rate of a secondary plant compound and the acquisition and persistence of aversions. British Journal of Nutrition 79(1): $55-62$.

Libert, B. \& Franceschi, V.R. 1987. Oxalate in crop plants. Journal of Agricultural and Food Chemistry 35(6): 926-938.

Masters, D.G., Norman, H.C. \& Barrett-Lennard, E.G. 2005. Agricultural systems for saline soil: The potential role of livestock. Asian-Australasian Journal of Animal Sciences 18(2): 296-300

Perry, T.W. 1984. Animal Life-Cycle Feeding and Nutrition. Orlando, Florida: Academic Press Inc. p. 299.

Rahman, M.M. \& Kawamura, O. 2011. Oxalate accumulation in forage plants: Some agronomic, climatic and genetic aspects. Asian-Australasian Journal of Animal Sciences 24(3): 439-448.

Rahman, M.M., Abdullah, R.B. \& Wan Khadijah, W.E. 2013. A review of oxalate poisoning in domestic animals: Tolerance and performance aspects. Journal of Animal Physiology and Animal Nutrition 97(4): 605-614.

Rahman, M.M., Nakagawa, T., Niimi, M., Fukuyama, K. \& Kawamura, O. 2011. Effects of feeding oxalate containing grass on intake and the concentrations of some minerals and parathyroid hormone in blood of sheep. Asian-Australasian Journal of Animal Sciences 24(7): 940-945.

Rahman, M.M., Niimi, M. \& Kawamura, O. 2007. Simple method for determination of oxalic acid in forages using high-performance liquid chromatography. Grassland Science 53(4): 201-204.

Rahman, M.M., Niimi, M., Ishii, Y. \& Kawamura, O. 2006. Effects of seasons, variety and botanical fractions on oxalate content of napiergrass (Pennisetum purpureum Schumach). Grassland Science 52(4): 161-166.

Roughan, P.G. \& Slack, C.R. 1973. Simple methods for screening and quantitative estimation of oxalate content of tropical grasses. Journal of the Science of Food and Agriculture 24(7): 803-811

The University of Tokyo. 1978. Jikken Nogei Kagaku. Laboratory of Agricultural Chemistry, Vol. 1. Tokyo: Asakura Publishing. pp. 276-277.

Van Soest, P.J., Robertson, J.B. \& Lewis, B.A. 1991. Methods of dietary fiber, neutral detergent fiber and non-starch polysaccharides in relation to animal nutrition. Journal of Dairy Science 74(10): 3583-3597.

Vonburg, R. 1994. Oxalic-acid and sodium oxalate. Journal of Applied Toxicology 14(3): 233-237.

Ward, G., Harbers, L.H. \& Blaha, J.J. 1979. Calcium-containing crystals in alfalfa: Their fate in cattle. Journal of Dairy Science 62(5): 715-722.

Mohammad Mijanur Rahman*, Md. Rokibur Rahman, Wan Embong Wan Khadijah \& Ramli bin Abdullah Institute of Biological Sciences

Faculty of Science, University of Malaya 50603 Kuala Lumpur, Federal Territory Malaysia

Mitsuhiro Niimi \& Ryo Akashi

Faculty of Agriculture, University of Miyazaki Miyazaki Shi 889-2192

Japan

*Corresponding author; email: mijanur@um.edu.my

Received: 27 February 2015

Accepted: 9 October 2016 